\title{
Grazing impact on autotrophic picoplankton in two south Andean lakes (Patagonia, Argentina) with different light:nutrient ratios
}

\author{
Impacto del pastoreo sobre picoplancton autotrófico en dos lagos andinos (Patagonia, \\ Argentina) con diferentes relaciones luz:nutrientes
}

ESTEBAN G. BALSEIRO, CLAUDIA P. QUEIMALIÑOS \& BEATRIZ E. MODENUTTI

Laboratorio de Limnología, Centro Regional Universitario Bariloche, Universidad Nacional del Comahue, Unidad Postal Universidad, 8400, Bariloche, Río Negro, Argentina; e-mail: balseiro@crub.uncoma.edu.ar

\begin{abstract}
Andean ultraoligotrophic lakes are environments with high light:nutrient ratios. In these lakes a particular planktonic food web has been noticed, constituted by large mixotrophic ciliates which share and compete for food resources with nanoflagellates and cladocerans. Clearance rates on autotrophic picoplankton of nanoflagellates, the ciliate Ophrydium naumanni and cladocerans were compared through grazing experiments in lakes Moreno Oeste and Rivadavia. The lakes exhibited significant differences in the light:nutrient ratio and had different crustacean and zooplankton compositions. In lake Moreno Oeste the metalimnion was included in the euphotic zone resulting in an illuminated layer where deep chlorophyll maxima developed. On the contrary, in lake Rivadavia the illuminated layers were restricted to the epilimnion and no deep chlorophyll maxima were observed. In lake Moreno Oeste, the contribution to total bacterivory of the ciliate $O$. naumanni and the cladoceran Ceriodaphnia dubia was observed to increase at $30 \mathrm{~m}$ depth, due mainly to the vertical distribution of both species. On the contrary, the grazing rates of the nanoflagellate assemblage, dominated by the mixotrophic Chrysochromulina parva, did not change along the water column and were considerably high (one order of magnitude higher than those obtained for $O$. naumanni and C. dubia). In lake Rivadavia, nanoflagellate grazing rates were lower and the relative impact of the nanoflagellate assemblage was comparable to those of $O$. naumanni and Daphnia cf .commutata. The observed difference in clearance rates of the nanoflagellate assemblage probably would reflect an increase in the phagotrophy where light energy is higher relative to phosphorus. In lake Moreno Oeste where light is not limiting, the observed increase of the phagotrophy by protists may be due to a higher requirement of limiting elements.
\end{abstract}

Key words: planktonic bacterivory, ultraoligotrophic lakes, mixotrophy, light:nutrient ratio, Ophrydium naumanni, nanoflagellates.

\section{RESUMEN}

Los lagos andino-patagónicos son ambientes con una alta relación luz:nutrientes. En estos lagos se ha descrito una red trófica particular constituida por grandes ciliados mixotróficos que comparten y compiten por recursos alimentarios con nanoflagelados y cladóceros. A través de experimentos de pastoreo se compararon las tasas de limpieza sobre picoplancton autotrófico de nanoflagelados; el ciliado Ophrydium naumanni y cladóceros de los lagos Moreno Oeste y Rivadavia. Estos lagos presentan diferencias significativas en cuanto a su relación luz:nutrientes y tienen también una composición de crustáceos del zooplancton diferente. En el lago Moreno Oeste, el metalimnion está incluido dentro de la zona eufótica, determinando un estrato iluminado en el que se desarrolla un máximo de clorofila en profundidad. En el lago Rivadavia, en cambio, los estratos iluminados están restringidos al epilimnion y no se observó ningún máximo de clorofila en profundidad. En el lago Moreno se observó que a $30 \mathrm{~m}$ de profundidad se producía un incremento en la proporción de la bacterivoría ejercida por el ciliado O. naumanni y el cladócero Ceriodaphnia dubia debido fundamentalmente a la distribución vertical de ambas especies. Por el contrario, las tasas de limpieza del conjunto de nanoflagelados, dominado por la especie mixótrofa Chrysochromulina parva, no presentaron cambios a lo largo de la columna de agua y fueron un orden de magnitud mayores que aquellas de O. naumanni y $C$. dubia. En el lago Rivadavia, las tasas de pastoreo de los nanoflagelados fueron menores y comparables con las obtenidas para $O$. naumanni y Daphnia cf. commutata. Las diferencias observadas en las tasas de limpieza de nanoflagelados probablemente reflejan un incremento de la fagotrofía donde la energía lumínica es alta en relación con el fósforo. De esta manera, en el lago Moreno Oeste, donde la luz no es limitante, el aumento observado en la bacterivoría de los protistas podría deberse a un mayor requerimiento de nutrientes limitantes.

Palabras clave: bacterivoría planctónica, lagos ultraoligotróficos, mixotrofía, relación luz:nutrientes, Ophrydium naumanni, nanoflagelados. 


\section{INTRODUCTION}

The role of bacteria and picoplankton as food resources for different planktonic organisms has long been recognised (Peterson et al. 1978, Güde 1989, Vaqué \& Pace 1992, Hart \& Jarvis 1993), and different groups of grazers including flagellates, ciliates, rotifers and crustaceans may compete for these resources (Güde 1989, Jürgens et al. 1994, Jürgens et al. 1997, Jones 2000). Metazoans and protozoans graze on bacteria and picoplankton, and the relative importance of each group on the bacteria grazing losses has been determined in natural environments (Sanders et al. 1989, Vaqué \& Pace 1992, Pernthaler et al. 1996, Simek et al. 1998, Callieri et al. 2002). In eutrophic lake Oglethorpe (USA) heterotrophic nanoflagellates (HNF) were observed to dominate grazing all time while mixotrophic flagellates were major grazers during winter and spring blooms (Sanders et al. 1989). In the oligomesotrophic Piburger See (Austria), HNF were responsible for up to $90 \%$ of total bacterivory (Pernthaler et al. 1996). Again, protists especially HNF have been observed to consume most of bacterial production in three mesotrophic and eutrophic reservoirs, but ciliates may become important bacterivores with increasing trophy of systems (Simek et al. 1998). Recently $80 \%$ of the carbon produced by picocyanobacteria is taken up by $\mathrm{HNF}$ and ciliates during the oligotrophication of Lago Maggiore, and particularly peritrichs emerged as the most efficient grazers (Callieri et al. 2002).

Rotifers and cladocerans also have been recorded to be effective in depressing bacteria (Sanders et al. 1989, Arndt 1993). In particular, Daphnia exerts a strong impact on picoplankton (Jürgens 1994, Callieri \& Stockner 2002).

Freshwater food webs vary when exposed to different light:nutrient and carbon:nutrient environments (Sterner et al. 1997, Elser et al. 2000a). Like autotrophs, metazoan herbivores have similar nutrient ratios, and although they vary across taxa, $\mathrm{C}: \mathrm{P}$ ratios vary more than $\mathrm{C}: \mathrm{N}$ ratios, consistent with the relative constancy of $\mathrm{N}$ content but not with that of $\mathrm{P}$ content in major biological molecules (Elser et al. 2000a, 2000b). Recent studies have shown that zooplankton reduces its growth and reproduction when fed on P-limited algae, even when food is provided at high concentrations (Sterner \& Hessen 1994, DeMott et al. 1998). At the same time, bacterivory may be an important strategy in phototrophic flagellates for acquiring nutrients during nutrient limitation (Nygaard \& Tobiesen 1993).
Bacteria in turn can be constrained by nutrient availability and resource elemental ratios that may alter their cellular composition (Sterner et al. 1995, Chrzanowski et al. 1996).

In Andean ultraoligotrophic lakes from the northern Patagonia of Argentina $\left(41^{\circ} \mathrm{S}, 71^{\circ} 30^{\prime}\right.$ W) a particular planktonic food web has been reported (Modenutti et al. 1998). Noticeably, the peritrich Ophrydium naumanni Pejler, a freshwater pelagic ciliate with endosymbiotic Chlorella, dominates the ciliate assemblage. A similar situation was described for the Chilean lake Pirehueico where Stentor spp. dominated the ciliate assemblage (Woelfl \& Geller 2002). In addition, nanoflagellates were observed to be dominated by mixotrophic species, such as Chrysochromulina parva Lackey and Rhodomonas lacustris (Pascher \& Ruttner) Javornicky (Queimaliños et al. 1999, Queimaliños 2002). Recently, a clear association between the abundance of $O$. naumanni and the vertical distribution of autotrophic picoplankton was recorded in lake Moreno Oeste, preferring both metalimnetic levels at or near $1 \%$ of surface PAR irradiance conforming Deep Chlorophyll Maxima (DCM) (Queimaliños et al. 1999, Modenutti \& Balseiro 2002, Pérez et al. 2002). In addition, this ciliate was also observed in other southern lakes of Argentina ( $42^{\circ} \mathrm{S}$ ) belonging to a different basin (Modenutti et al. 2003). In particular, in lake Rivadavia the development of a DCM was not observed and $O$. naumanni vertical distribution did not show remarkable shifts along the water column (Modenutti et al. 2003). These features allowed us to hypothesize that lakes Moreno Oeste and Rivadavia would differ in their light:nutrient ratios. Moreover, these two lakes present a different crustacean zooplankton structure with larger organisms like Daphnia cf. commutata Ekman (Daphnia middendorffiana Fischer, sensu J. C. Paggi) in lake Rivadavia (Modenutti et al. 1998, Modenutti et al. 2003). Ophrydium naumanni was observed with autotrophic picoplankton inside its food vacuoles and it was able to ingest particles in field and laboratory experiments (Modenutti \& Balseiro 2002). Therefore, this particular ciliate would share and compete for food resources with flagellates and cladocerans. The aim of the present study was to compare the clearance rates on picoplankton of nanoflagellates, $O$. naumanni and cladocerans in two Andean lakes with different crustacean zooplankton structures. We propose that the grazing rates of $O$. naumanni and nanoflagellates would differ according to light:nutrient ratio, trophic structure and the presence of large cladocerans. 


\section{MATERIAL AND METHODS}

\section{Study area and sampling}

We conducted our study in two lakes of the Andean-Patagonian region (Argentina) with different crustacean community structure: lake Moreno Oeste $\left(41^{\circ} 5^{\prime} \mathrm{S}, 71^{\circ} 33^{\prime}, \mathrm{W}, 758 \mathrm{~m}\right.$ of altitude) and lake Rivadavia ( $42^{\circ} 34^{\prime} \mathrm{S}, 71^{\circ} 39^{\prime}$ W, $500 \mathrm{~m}$ of altitude). Lake Moreno Oeste has an area of $6 \mathrm{~km}^{2}$ and a maximum depth of $90 \mathrm{~m}$ and belongs to the Nahuel Huapi System of Atlantic watershed. Lake Rivadavia has a surface area of $21.70 \mathrm{~km}^{2}$ and a maximum depth of $147 \mathrm{~m}$ and belongs to the Futaleufú basin of Pacific watershed. Both lakes have a warm monomictic thermal regime, with a stratification period during late spring and summer (November until April) (Queimaliños et al. 1999, Modenutti et al. 2003).

The lakes were compared based on field work done on several occasions during the spring-summer season (September 2001 to March 2002). Water samples were obtained from a central sampling point located at the deepest part of both lakes. Samples were collected with a $12 \mathrm{~L}$ Schindler-Patalas trap from 0 to $50 \mathrm{~m}$ at $5 \mathrm{~m}$ intervals, and subdivided in different sampling bottles for different purposes: determination of nutrient and chlorophyll concentrations, enumeration of bacteria, picoplankton, phytoplankton and ciliates. Cladocerans were obtained also with a Schindler-Patalas trap and filtered through a plankton net of $55 \mu \mathrm{m}$ mesh size. For this purpose a volume of $60 \mathrm{~L}$ were collected (five Schlinder-Patalas trap). Rotifers and copepods were not analysed in this study. All samplings were carried out at mid-day, $1 \mathrm{~h}$ before astronomic noon. Temperature and light (Photosynthetically Active Radiation, PAR, 400-700 $\mathrm{nm}$ ) profiles were measured with a PUV 500B submersible radiometer (Biospherical Instruments). Chlorophyll-a profiles (for DCM depth estimation) were obtained from natural fluorescence from the PUV 500B, calibrated with a laboratory Fluorometer (Turner AU10 Fluorometer).

We collected water and cladocerans for experimentation and estimation of cladoceran abundance during summer 2002 at the same sampling site with a closing Bongo net of 48 $\mu \mathrm{m}$ and $202 \mu \mathrm{m}$ mesh size.

\section{Phosphorus and chlorophyll-a determination}

Phosphorus and chlorophyll- $a$ were determined in the laboratory from samples transported immediately from the field in darkness and thermally isolated. Samples for determining chlorophyll- $a$ concentration were filtered onto $\mathrm{GF} / \mathrm{F}$ filters and extracted with hot ethanol (Nusch 1980) and measured on a 10-AU fluorometer (Turner Designs). Total phosphorus (TP) was estimated on $250 \mathrm{~mL}$ of unfiltered lake water and total dissolved phosphorus (TDP) on $250 \mathrm{~mL}$ precombusted $\mathrm{GF} / \mathrm{F}$ filtered lake water. Phosphorus concentration was measured spectrophotometrically after digestion with potassium persulfate (APHA 1989). Total particulate phosphorus (TPP) was calculated by difference between TP and TDP.

Bacteria and picoplankton abundance and fluorescently labelled cells (FLC) preparation

Samples $(60 \mathrm{~mL})$ for total bacteria enumeration were fixed with formaldehyde (final concentration $2 \% \mathrm{v} / \mathrm{v}$ ) and stained with fluorochrome 4', 6-diamidino-2-phenylindole (DAPI; final concentration $0.2 \% \mathrm{w} / \mathrm{v}$ ) according to Porter \& Feig (1980). Samples (60 $\mathrm{mL}$ ) for autotrophic picoplankton enumeration were fixed with formaldehyde-cacodylate. Samples were stored in darkness and refrigerated, and quantified within two weeks of sampling. Counting was performed on black polycarbonate filters (Poretics, $0.2 \mu \mathrm{m}$ pore size) at 1,000 X magnification in an Olympus BX50 epifluorescence microscope using UV light (U-MWU filter) for total bacteria, and blue light (U-MWB filter) for autotrophic picoplankton. A minimum of 1,000 bacteria per sample were counted and processed with an image analysis system (Image ProPlus, Media Cybernetics). Biovolume of bacteria and autotrophic picoplankton was calculated on the basis of these measurements.

Fluorescently labelled cells (FLC) were prepared by centrifugation of Synechococcus cells from a batch culture kindly provided by Dr. C. Callieri from the CNR-Istituto per lo Studio degli Ecosistemi, Pallanza, Italy. Cells were stained with 5-[(4,6-dichlorotriazin-2yl)amino] fluorescein (DTAF) according to Sherr et al. (1987). FLC were stored frozen in 1 $\mathrm{mL}$ aliquots. The resultant FLC were coccoidshaped of $0.90 \mu \mathrm{m}(\mathrm{SE}=0.07)$ in diameter.

Ophrydium naumanni, nanoflagellate and cladoceran abundances

Protist cells were quantified from $250 \mathrm{~mL}$ samples fixed with Lugol solution. Nanoflagellate and enumeration of other phytoplankton species were performed 
following Utermöhl technique (Utermöhl 1958) at 400x. The limit between nano and net phytoplankton was considered as $20 \mu \mathrm{m}$ GALD (Greatest Axial Linear Dimension). Ophrydium cells were enumerated with an inverted microscope using $50 \mathrm{~mL}$ Utermöhl chambers and quantification was carried out by scanning the entire surface of the chamber at $200 \mathrm{X}$ magnification.

In addition, a volume of $60 \mathrm{~mL}$ was preserved with buffered formaldehyde (final concentration, $2 \% \mathrm{v} / \mathrm{v}$ ) for nanoflagellate counting and to distinguish heterotrophic nanoflagellates (HNF) from phototrophic nanoflagellates (PNF, which includes autotrophic and mixotrophic species). Samples were stored refrigerated in darkness, and quantified within two weeks of sampling. A volume of $40 \mathrm{~mL}$ was filtered onto $1 \mu \mathrm{m}$ black membrane filters (Poretics) for the enumeration of nanoflagellates and stained with fluorochrome 4', 6-diamidino-2-phenylindole (DAPI; final concentration $0.2 \% \mathrm{w} / \mathrm{v}$ ) according to Porter \& Feig (1980). Cells were counted by means of epifluorescence microscopy at 1,000 X, using both UV and blue light, to distinguish HNF and PNF respectively (Kemp et al. 1993).

At least 30 cells of each nanoflagellate and other phytoplankton species were measured and cell biovolume was calculated by approximation to appropriate geometric figures. The biovolume of Ophrydium naumanni was estimated based on Balseiro et al. (2001) with an equivalent spherical diameter (ESD) of $54 \mu \mathrm{m}$.

Cladoceran species were counted under a stereomicroscope in a $5 \mathrm{~mL}$ Bogorov chamber. Body size was estimated with a graduated eyepiece. Rotifers and copepods were not analysed in this study.

\section{Grazing experiments}

In each lake (Moreno Oeste and Rivadavia) two series of in situ grazing experiments were carried out on 19 February and 2 March 2002 with FLC. Water samples (2 L) were collected at 10 and $30 \mathrm{~m}$ depth. Grazing experiments were performed in two replicates using $300 \mathrm{~mL}$ ground-stoppered flasks, in which $250 \mathrm{~mL}$ of the collected water were dispensed. After 20 min of acclimation, FLC were added to a final concentration of $1.4 \times 10^{5} \mathrm{~mL}^{-1}$ (equivalent to approximately $9-11 \%$ of total bacteria abundance in both lakes). The flasks were incubated in the lake at $20 \mathrm{~m}$ depth. Concurrently, cumulative irradiance during the experiment was obtained with a PUV 500 radiometer. Subsamples of $40 \mathrm{~mL}$ were taken at 5, 10, 15, 20 and $40 \mathrm{~min}$ after FLC addition. These samples were fixed with $0.5 \%$ of Lugol solution, followed by $2 \%$ formaldehyde and several drops of $3 \%$ sodium thiosulphate to clear the colour (Sherr \& Sherr 1993). Within three days after fixation, $40 \mathrm{~mL}$ were stained with DAPI and filtered through $1 \mu \mathrm{m}$ black polycarbonate filters (Poretics). The number of ingested prey (FLC) was quantified with an epifluorescence microscope (Olympus BX50) and the same image analysis system.

Clearance rates were calculated by linear regression of average number of FLC per ciliate or nanoflagellate versus time (Sherr \& Sherr 1993). To estimate total Ophrydium or nanoflagellate grazing rates, average grazing rates were multiplied by total in situ abundances at 10 or $30 \mathrm{~m}$ depth.

Cladoceran grazing rates were obtained with another series of laboratory experiments. These measurements were performed for the dominant cladoceran species in each lake, Ceriodaphnia dubia Richard in lake Moreno Oeste and Daphnia cf. commutata in lake Rivadavia. Cladoceran population clearance rates were calculated based on in situ abundances at 10 and $30 \mathrm{~m}$ depth for Ceriodaphnia and $30 \mathrm{~m}$ for Daphnia. Clearence rates of $C$. dubia were previously obtained feeding on algae from a culture (Martínez 2000) as well as on natural phytoplanktonic cells (Matveev \& Balseiro 1990).

Lake water (Moreno Oeste or Rivadavia) was filtered through a $2 \mu \mathrm{m}$ pore size membrane filter (Osmonics) allowing natural bacteria to pass through the filter. Then, Synechococcus cells from the same batch culture for FLC preparation were added. Samples for total bacteria enumeration were obtained at the beginning of each experiment. Initial concentrations during the experiments were 2.6 to $2.810^{5}$ cells $\mathrm{mL}^{-1}$ of Synechococcus cells and 1 to $1.210^{6}$ cells $\mathrm{mL}^{-1}$ of total bacteria. Grazing experiments were performed using $150 \mathrm{~mL}$ ground-stoppered flasks, in which $150 \mathrm{~mL}$ of filtered lake water + Synechococcus were dispensed. Each experiment consisted in the incubation of water with and without grazers (experimental treatment and control). Both treatments and controls were run in three replicates and were maintained for $24 \mathrm{~h}$ in a growth chamber at $15{ }^{\circ} \mathrm{C}$ and a $14: 10$ light:dark photoperiod; light intensity inside the chamber was $39.0 \mu \mathrm{mol} \mathrm{m}^{-2} \mathrm{~s}^{-1}$. We run two experiments (20 February and 3 March 2002) with $C$. dubia as grazer collected from $30 \mathrm{~m}$ depth from lake Moreno Oeste. We added 15 C. dubia adults of approximately $0.6 \mathrm{~mm}$ body length per flask in 
our experimental treatments. We also carried out one experiment (20 March 2001) with $D$. cf . commutata and each flask contained five adults averaging $2.2 \mathrm{~mm}$ in body length collected from $30 \mathrm{~m}$ depth of lake Rivadavia. At $24 \mathrm{~h}$ of incubation, a volume of $60 \mathrm{~mL}$ of water was obtained for bacteria and Synechococcus enumeration as described before.

To assess clearance rates, the Gauld formula (Gauld 1951) was applied as it follows:

$$
C R=\frac{V\left(\ln C_{0}-\ln C_{1}\right)}{\mathrm{t} \times N}
$$

where $\mathrm{V}=$ volume of the flasks in $\mathrm{mL}, \mathrm{t}=$ time during which the animals fed, $\mathrm{N}=$ number of the animals, $\mathrm{C}_{0}=$ initial cell concentration, and $\mathrm{C}_{t}=$ final cell concentration .

\section{Data analysis}

Diffuse PAR attenuation coefficients $\left(\mathrm{K}_{\mathrm{d} \text { PAR }}\right)$ were determined from the slope of the linear regression of the natural logarithm of down welling PAR irradiance versus depth. We calculated the Mean Light of Mixing Layer $\left(\mathrm{I}_{\mathrm{m}}\right)$ and the Light/Phosphorus ratio $\left(\mathrm{I}_{\mathrm{m}} / \mathrm{TP} \mu \mathrm{mol} \mathrm{\textrm {L } ^ { - }}\right.$ ${ }^{1}$ ) by combining $K_{d}$ values, data of mixing layer depth, TP concentration from both lakes
(Sterner et al. 1997), and according to the formula:

$$
I_{m}=\frac{1-e^{-K_{d} \cdot z m}}{K_{d} \cdot z_{m}}
$$

where $z_{m}$ indicates the depth of the mixing layer.

Based on the light- nutrient model of Sterner et al. (1997) we approximated the sestonic C:P ratio of both lakes.

Total Sestonic Biovolume (TSB) was estimated as the sum of bacteria, autotrophic picoplankton, phytoplankton and ciliate biovolumes. Comparisons between lakes in terms of light:phosphorus and TSB:TPP ratios were carried out with one-way ANOVA tests. Normality and homocedasticity were previously tested.

\section{RESULTS}

\section{Comparison of lakes Moreno Oeste and Rivadavia}

Both lakes are ultraoligotrophic, with epilimnetic chlorophyll- $a$ concentrations of less than $2 \mu \mathrm{g} \mathrm{L}^{-1}$ and total phosphorus between 2 and $6 \mu \mathrm{g} \mathrm{L}^{-1}$ (Tables 1 and 2). Nevertheless, the lakes differed markedly in the vertical

Limnological features (average values each $5 \mathrm{~m}$ intervals) of lake Moreno Oeste at the mixed layer (ML) and at the deep chlorophyll maxima (DCM) during the spring summer season 2001-2002. Key to abbreviations: TPP $=$ total particulate phosphorus; $\mathrm{TP}=$ total phosphorus; na $=$ not available

Características limnológicas (valores medios a intervalos de $5 \mathrm{~m}$ ) del lago Moreno Oeste en la capa de mezcla (ML) y en el nivel del máximo profundo de clorofila (DCM) durante la primavera-verano 2001-2002.

\begin{tabular}{|c|c|c|c|c|c|c|}
\hline Date & $\begin{array}{c}1 \% \text { PAR } \\
\text { depth }(m)\end{array}$ & $\begin{array}{c}\text { ML \& DCM } \\
\text { depth (m) }\end{array}$ & $\begin{array}{c}\text { Chl- } a \\
\left(\mu \mathrm{g} \mathrm{L}^{-1}\right)\end{array}$ & $\begin{array}{c}\mathrm{TPP} \\
\left(\mu \mathrm{g} \mathrm{L}^{-1}\right)\end{array}$ & $\begin{array}{c}\mathrm{TP} \\
\left(\mu \mathrm{g} \mathrm{L}^{-1}\right)\end{array}$ & $\begin{array}{l}\text { Total sestonic } \\
\text { biovolume } \\
\left(10^{5} \mu \mathrm{m}^{3} \mathrm{~mL}^{-1}\right)\end{array}$ \\
\hline \multirow[t]{2}{*}{16 November } & 38 & ML 25 & 0.58 & 1.78 & 3.50 & 3.16 \\
\hline & & DCM 36 & 0.78 & 1.07 & 3.04 & 8.42 \\
\hline \multirow[t]{2}{*}{12 December } & 35 & ML 25 & 0.78 & 2.22 & 4.48 & 6.32 \\
\hline & & DCM 28 & 1.30 & 1.32 & 3.04 & 10.22 \\
\hline \multirow[t]{2}{*}{25 January } & 33 & ML 28 & 1.62 & 1.93 & 3.61 & 4.83 \\
\hline & & DCM 33 & 2.26 & 1.63 & 3.45 & 10.56 \\
\hline \multirow[t]{2}{*}{19 February } & 33 & ML 23 & 0.44 & 1.68 & 2.79 & 5.16 \\
\hline & & DCM 25 & 1.40 & 1.80 & 2.79 & 6.52 \\
\hline \multirow[t]{2}{*}{7 March } & 31 & ML 30 & 0.61 & na & na & 7.80 \\
\hline & & DCM 32 & 1.70 & na & na & 11.52 \\
\hline
\end{tabular}
Abreviaciones: TPP = fósforo total particulado; TP = fósforo total; na $=$ no disponible 
TABLE 2

Limnological features (average values each $5 \mathrm{~m}$ intervals) of lake Rivadavia at the mixed layer during the spring summer season 2001-2002. Key to abbreviations: $\mathrm{TPP}=$ total particulate phosphorus; $\mathrm{TP}=$ total phosphorus

Características limnológicas (valores medios a intervalos de $5 \mathrm{~m}$ ) del lago Rivadavia en la capa de mezcla durante la primavera-verano 2001-2002. Abreviaciones: TPP = fósforo total particulado; TP = fósforo total

\begin{tabular}{|c|c|c|c|c|c|c|}
\hline Date & $\begin{array}{l}1 \% \text { PAR } \\
\text { Depth }(\mathrm{m})\end{array}$ & $\begin{array}{l}\text { Mixed layer } \\
\text { depth }(\mathrm{m})\end{array}$ & $\begin{array}{l}\text { Chl- } a \\
\left(\mu \mathrm{g} \mathrm{L}^{-1}\right)\end{array}$ & $\begin{array}{c}\text { TPP } \\
\left(\mu \mathrm{g} \mathrm{L}^{-1}\right)\end{array}$ & $\begin{array}{c}\mathrm{TP} \\
\left(\mu \mathrm{g} \mathrm{L}^{-1}\right)\end{array}$ & $\begin{array}{l}\text { Total sestonic biovolume } \\
\qquad\left(10^{5} \mu \mathrm{m}^{3} \mathrm{~mL}^{-1}\right)\end{array}$ \\
\hline 28 September & 23 & Mixed & 1.80 & 1.93 & 4.23 & 5.21 \\
\hline 19 November & 18 & 23 & 1.82 & 2.87 & 6.22 & 4.90 \\
\hline 7 December & 20 & 30 & 1.65 & 2.63 & 4.85 & 4.77 \\
\hline 20 February & 31 & 30 & 1.41 & 2.33 & 4.63 & 7.69 \\
\hline 2 March & 21 & 32 & 1.65 & 3.41 & 6.82 & 9.21 \\
\hline
\end{tabular}

distribution of the euphotic zone (1\% of surface PAR irradiance), and metalimnetic layers. In lake Moreno Oeste the metalimnion was included in the euphotic zone resulting in an illuminated layer where Deep Chlorophyll Maxima developed (Table 1). On the contrary, in lake Rivadavia only $1 \%$ of surface PAR irradiance reached the metalimnion in one occasion (February sampling). Therefore, the illuminated layers were restricted to the epilimnion and no deep chlorophyll maximum was observed (Table 2). As a consequence, the vertical distribution of the biovolume of different sestonic fractions varied between lakes. In lake Moreno Oeste all autotrophic fractions increased their relative importance at the Deep
Chlorophyll Maxima, while in lake Rivadavia the biovolume was more homogenously distributed in the epilimnion (Fig. 1).

Although both lakes had low concentrations of phosphorus, slightly higher values of both total phosphorus and total particulate phosphorus were observed in lake Rivadavia (Tables 1 and 2). Based on the biovolume calculation of different components of the planktonic community, we observed that the TSB to TPP ratio differed significantly between both lakes (ANOVA, P $<0.01$, Table 3). Mean light in the mixed layer $\left(\mathrm{I}_{\mathrm{m}}\right)$ differed between both lakes being the epilimnion of lake Moreno Oeste more illuminated than that of lake Rivadavia (Table 4). As the former has lower

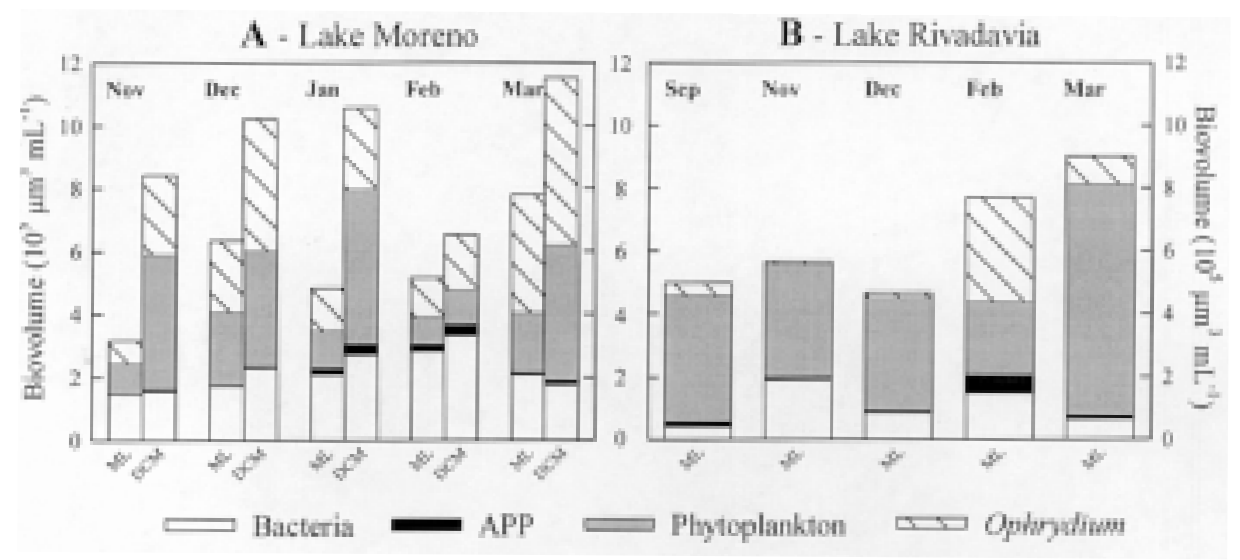

Fig. 1: Biovolume of different sestonic fractions at the mixed layer (ML), and at the deep chlorophyll maxima (DCM) in lakes (A) Moreno Oeste and (B) Rivadavia.

Biovolumen de las diferentes fracciones sestónicas en la capa de mezcla (ML) y en el nivel del máximo profundo de clorofila en los lagos (A) Moreno Oeste y (B) Rivadavia. 
TABLE 3

ANOVA result comparing the ratio Total Sestonic Biovolume to Total Particulate Phosphorus (TSB:TPP) between lakes Moreno Oeste and Rivadavia

Resultados del ANOVA comparando la relación Biovolumen Total Sestónico:

Fósforo Particulado Total (TSB:TPP) entre los lagos Moreno Oeste y Rivadavia

\begin{tabular}{|c|c|c|c|c|c|}
\hline Source of variance & Degree of freedom & Sum of squares & Mean square & F-value & P-value \\
\hline Between lakes & 1 & 163190.4 & 163190.4 & 16.6 & 0.0036 \\
\hline Residual & 8 & 78618.4 & 9827.3 & & \\
\hline Total & 9 & 241808.8 & & & \\
\hline
\end{tabular}

TABLE 4

Light parameters and light:nutrient ratios in lakes Moreno Oeste and Rivadavia during the spring summer season 2001-2002; C:P estimation based on the model of Sterner et al. (1997)

Parámetros de luz y relación luz:nutrients en los lagos Moreno Oeste y Rivadavia durante la primavera-verano 2001-2002. Estimación del cociente C:P se basó en el modelo de Sterner et al. (1997)

\begin{tabular}{|c|c|c|c|c|c|}
\hline Lake & Date & $K_{d}\left(\mathrm{~m}^{-1}\right)$ & $\mathrm{I}_{m}$ & Light:phosphorus & Estimated C:P \\
\hline \multicolumn{6}{|c|}{ Moreno } \\
\hline & 16 Nov & 0.12 & 0.317 & 2.805 & 451 \\
\hline & $12 \mathrm{Dec}$ & 0.13 & 0.296 & 2.047 & 397 \\
\hline & 25 Jan & 0.14 & 0.250 & 2.147 & 404 \\
\hline & $19 \mathrm{Feb}$ & 0.14 & 0.298 & 3.313 & 487 \\
\hline & 7 Mar & 0.15 & 0.220 & n.a. & n.a. \\
\hline \multicolumn{6}{|c|}{ Rivadavia } \\
\hline & $28 \mathrm{Sep}$ & 0.20 & & Not stratified & \\
\hline & 19 Nov & 0.25 & 0.173 & 0.844 & 311 \\
\hline & $7 \mathrm{Dec}$ & 0.23 & 0.124 & 0.590 & 293 \\
\hline & $20 \mathrm{Feb}$ & 0.15 & 0.207 & 1.383 & 350 \\
\hline & 2 Mar & 0.22 & 0.130 & 0.816 & 309 \\
\hline
\end{tabular}

phosphorus concentration (Table 1 and 2), the light:phosphorus ratio differed between lakes (ANOVA, $\mathrm{P}<0.01$, Table 5). After using these data along with the model of Sterner et al. (1997), we estimated that the C:P ratio of lake Rivadavia reached values near 300 , whereas lake Moreno Oeste reached values near 450.

The nanoflagellate assemblage dominated the phytoplanktonic community in both lakes, and it was characterised by mixotrophic species like the Prymnesiophycean Chrysochromulina parva and the cryptophycean Rhodomonas lacustris. In lake Moreno Oeste the nanoflagellate total abundance (including HNF) varied between 360 and 681 cell $\mathrm{mL}^{-1}$, and $C$. parva was the dominant species, with a contribution reaching $90 \%$. On the contrary, the relative abundance of HNF was low, varying between 2 and $9 \%$ of the total nanoflagellate abundance.

In lake Rivadavia, the total nanoflagellate abundance was comparatively lower, varying between 234 and 425 cell $\mathrm{mL}^{-1}$, and $C$. parva represented up to $70 \%$ of this total abundance. Nevertheless, other mixotrophic chrysophycean species (Ochromonas spp.) had an important contribution to total nanoflagellate abundance, while HNF abundances were observed to be low (less than $10 \%$ of total abundance).

The peritrich $O$. naumanni dominated the ciliate assemblage in both lakes, with densities varying between 2 to 6 cell $\mathrm{mL}^{-1}$. In lake Moreno Oeste, O. naumanni showed an increase in cell abundance at or below $30 \mathrm{~m}$ 
TABLE 5

ANOVA results comparing the light: phosphorus ratio between lakes Moreno Oeste and Rivadavia

Resultados del ANDEVA realizado para comparar la relación luz: fósforo entre los lagos Moreno Oeste y Rivadavia

\begin{tabular}{|c|c|c|c|c|c|}
\hline Source of variance & Degree of freedom & Sum of squares & Mean square & F-value & $\mathrm{P}$-value \\
\hline Between treatments & 1 & 5.15 & 5.146 & 21.9 & 0.0034 \\
\hline Residual & 6 & 1.41 & 0.235 & & \\
\hline Total & 7 & 6.56 & & & \\
\hline
\end{tabular}

depth, near the limit of the euphotic zone and just below the upper limit of the metalimnion. This species did not exhibit a regular pattern in its distribution in lake Rivadavia as it developed maximum abundances at $10 \mathrm{~m}$ or below $20 \mathrm{~m}$ depth ( $1 \%$ of surface PAR), and this distribution was not related with the thermocline of the lake.

Crustacean zooplankton composition also differed between the two lakes. In lake Moreno Oeste, the crustacean zooplankton assemblage was constituted by smaller species (less than 1 $\mathrm{mm}$ in body length), and was dominated by the calanoid copepod Boeckella gracilipes Daday and the cladoceran C. dubia. Although in lake Rivadavia crustacean zooplankton was also dominated by a small calanoid species, Boeckella michaelseni (Mrázek), larger zooplankters (> $1 \mathrm{~mm}$ in body length) were common. This particular assemblage was constituted by the large cladoceran Daphnia cf. commutata and the predaceous calanoid Parabroteas sarsi Daday. The vertical distribution of cladoceran species in both lakes showed a clear preference for areas located below the $1 \%$ of surface PAR irradiance during daytime. In lake Rivadavia, Daphnia cf. commutata reached up to 160 ind $\mathrm{m}^{-3}$ from 30 to $50 \mathrm{~m}$, while in lake Moreno, $C$. dubia showed a mean of 1,000 ind $\mathrm{m}^{-3}$ from 10 to 25 $\mathrm{m}$, and 8,000 ind $\mathrm{m}^{-3}$ from 30 to $50 \mathrm{~m}$.

Grazing by nanoflagellates, ciliates and cladocerans

Cumulative irradiance was observed to be very similar in both lakes, although in lake Moreno Oeste was slightly higher (Fig. 2). Both nanoflagellates (including mixotrophic nanoflagellates and HNF) and the ciliate $O$. naumanni were able to feed upon the FLC offered as prey. Nanoflagellate ingestion increased during the first $10 \mathrm{~min}$ of incubation, resulting in clearance rates of $0.042 \mu \mathrm{L}$ flagellate ${ }^{-1} \mathrm{~h}^{-1}$ and $0.033 \mu \mathrm{L}$ flagellate $\mathrm{e}^{-1} \mathrm{~h}^{-1}$ in lake Moreno Oeste at 10 and $30 \mathrm{~m}$ depth,

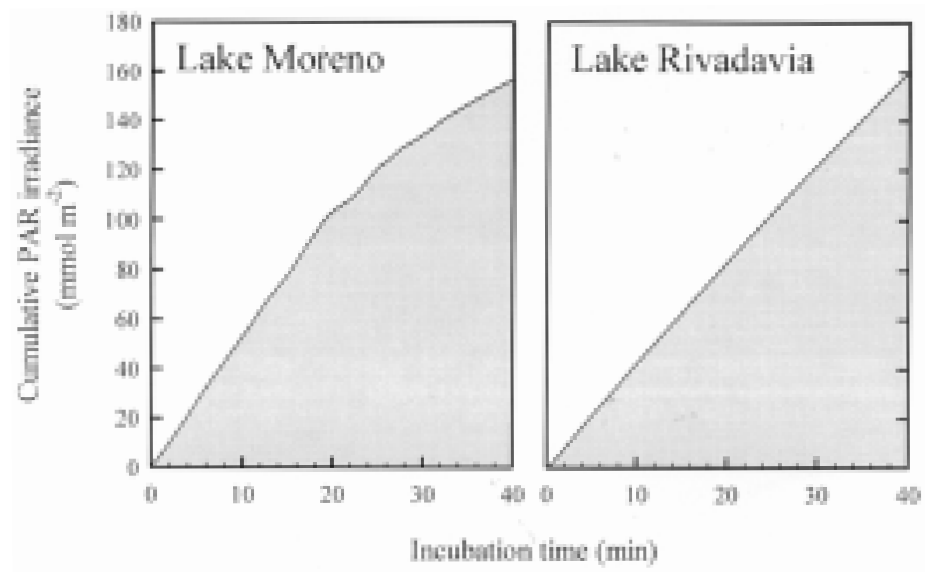

Fig. 2: Cumulative radiation during the grazing experiments at $20 \mathrm{~m}$ depth in lakes Moreno Oeste and Rivadavia.

Radiación acumulada durante los experimentos de pastoreo a 20 m de profundidad en los lagos Moreno Oeste y Rivadavia. 
respectively (Fig. 3). In lake Rivadavia, the values recorded were comparatively lower, varying between $0.018 \mu \mathrm{L}$ flagellate ${ }^{-1} \mathrm{~h}^{-1}$ (at 10 $\mathrm{m}$ depth) and $0.015 \mu \mathrm{L}$ flagellate ${ }^{-1} \mathrm{~h}^{-1}$ (at $30 \mathrm{~m}$ depth) (Fig. 3).

Ingestion by Ophrydium naumanni of FLC increased with time up to $40 \mathrm{~min}$ of incubation (Fig. 4). In lake Moreno Oeste, the ciliate clearance rate was $0.39 \mu \mathrm{L}$ ciliate $^{-1} \mathrm{~h}^{-1}$ (at 10 $\mathrm{m}$ depth) and $0.37 \mu \mathrm{L}$ ciliate ${ }^{-1} \mathrm{~h}^{-1}$ (at $30 \mathrm{~m}$ depth). Similar results were obtained in lake Rivadavia with rates varying between 0.24 and $0.31 \mu \mathrm{L}$ ciliate $^{-1} \mathrm{~h}^{-1}$ at 10 and $30 \mathrm{~m}$ depth, respectively. Nevertheless, rates were comparatively lower in lake Rivadavia than in lake Moreno Oeste (Fig. 4).

Cladoceran clearance rates differed substantially between lakes because of size differences of the species involved. In lake Moreno Oeste the obtained clearance rate of $C$. dubia (0.6 mm in body length) was of 0.35 (SE $\pm 0.03) \mathrm{mL}_{\text {ind }}^{-1} \mathrm{~h}^{-1}$ while the large $D$. cf. commutata ( $2.2 \mathrm{~mm}$ in body length) of lake Rivadavia attained rates of $1.77(\mathrm{SE} \pm 0.18) \mathrm{mL}$ ind $^{-1} \mathrm{~h}^{-1}$.

Vertical estimates of grazing were based on clearance rates obtained through our field and laboratory experiments and natural nanoflagellates (mixotrophic and HNF), $O$. naumanni and cladoceran abundances. The relative importance of grazing by the different groups varied along the water column (Table $6)$. In particular, the contribution to total bacterivory of the ciliate $O$. naumanni and the cladoceran $C$. dubia in lake Moreno Oeste increased at $30 \mathrm{~m}$ depth (Table 6). Ophrydium naumanni showed both an increase in individual clearance rate and in density, while C. dubia increased in density only. On the contrary, grazing rates within the nanoflagellate assemblage, dominated by the mixotrophic $C$. parva, did not change along the water column,

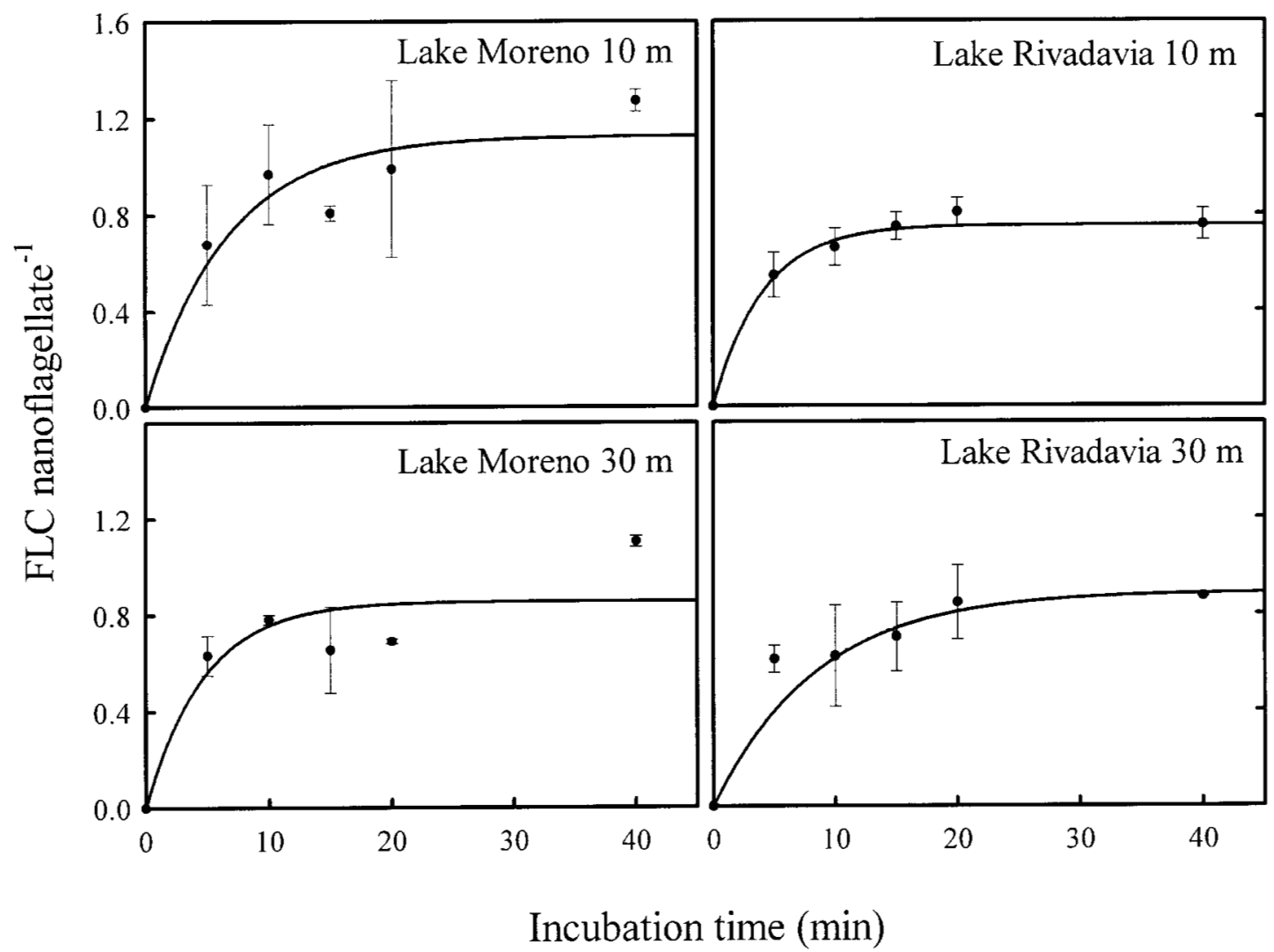

Fig. 3: Number of ingested FLC by the nanoflagellate assemblage from 10 and $30 \mathrm{~m}$ depth over time in the grazing experiments (Lakes Moreno Oeste and Rivadavia). Error bars represent standard errors.

Número de FLC ingeridas por el conjunto de nanoflagelados a 10 y $30 \mathrm{~m}$ de profundidad durante los experimentos de pastoreo (lagos Moreno Oeste y Rivadavia). Las barras de error indican error estándar. 


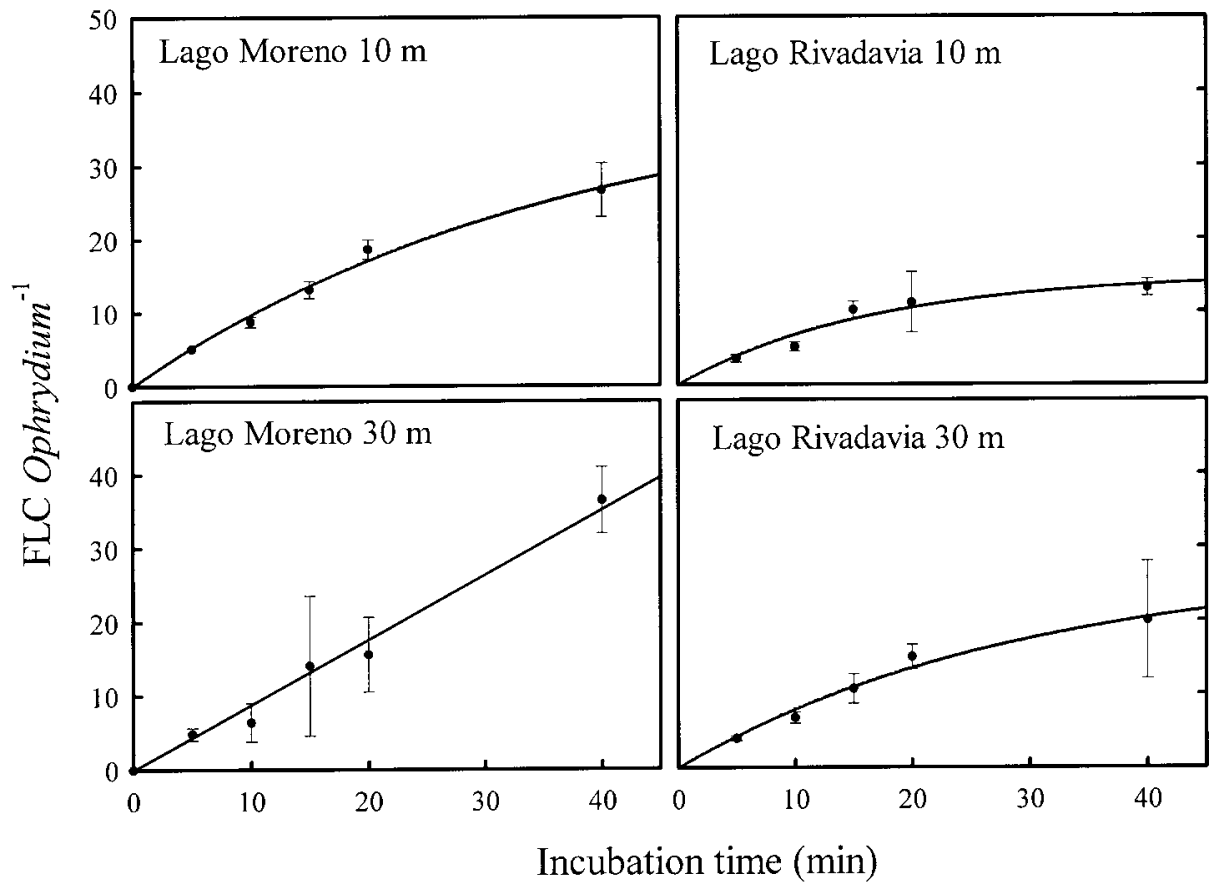

Fig. 4: Number of ingested FLC by Ophrydium naumanni from 10 and $30 \mathrm{~m}$ depth over time in the grazing experiments (Lakes Moreno Oeste and Rivadavia). Error bars represent standard errors.

Número de FLC ingeridas por Ophrydium naumanni a 10 y $30 \mathrm{~m}$ de profundidad durante los experimentos de pastoreo (lagos Moreno Oeste y Rivadavia). Las barras de error indican error estándar.

and were high; one order of magnitude higher than those obtained for $O$. naumanni and $C$. dubia (Table 6). Noticeably, in lake Rivadavia the nanoflagellate grazing rates were lower (Table 6) and the relative impact of the nanoflagellate assemblage was comparable to that of $O$. naumanni and $D$. cf. commutata. During daytime, Daphnia contributed to bacterivory at $30 \mathrm{~m}$ depth only, whereas ciliates and nanoflagellates contributed more at the upper level (Table 6).

\section{DISCUSSION}

Lakes with relatively high availability of solar radiation compared to phosphorus will be carbon rich and phosphorus poor in many ways, including the composition of algal biomass and the factors that limit growth at various trophic levels (Sterner et al. 1997). Therefore, where luminous energy is high relative to phosphorus, phytoplanktonbacteria-, and zooplankton are all predicted to show nutrient limitation (Sterner et al. 1997). In this study, lake Moreno Oeste and lake Rivadavia were observed to have significant differences in light:phosphorus ratios. In addition, the estimation of the C:P ratio, based on the model of Sterner et al. (1997), differed between both lakes, with values near 300 in lake Rivadavia and circa 450 in lake Moreno Oeste. This difference may be responsible for the differences in the composition of crustacean zooplankton, particularly regarding the presence of the large $D$. cf. commutata. Daphnia has high body P levels (Andersen \& Hessen 1991), and is known to be sensitive to $P$ deficiency (Sterner 1993). It can be predicted that lakes with low light:phosphorus ratios will have herbivores that are $\mathrm{C}$ limited, whereas herbivores in lakes with high light:phosphorus ratios will be $\mathrm{P}$ limited, depending on the demands of individual taxa (Sterner et al. 1997). Therefore, in lakes with $\mathrm{C}: \mathrm{P}$ ratios lower than 300 (where Daphnia occurred, Sterner et al. 2000) a strong effect on bacteria by cladocerans can be also expected (Vaqué \& Pace 1992, Jürgens 1994). In lake Rivadavia, $D$. cf. commutata attained higher clearance rates compared with the other bacterivorous groups. Moreover, a strong effect of Daphnia on picocyanobacteria has been recorded in a previous study (Modenutti 
Individual (Ind), population (Pop) and assemblage (Ass) clearance rates of protists and cladocerans in Lakes Moreno Oeste and Rivadavia, during February and March 2002 experiments

Tasas de limpieza individuales (Ind), poblacionales (Pop) y de conjunto (Ass) de protistas y cladóceros en los lagos Moreno Oeste y Rivadavia, durante los experimentos de febrero y marzo de 2002

\begin{tabular}{|c|c|c|c|c|c|c|c|c|c|}
\hline \multirow[t]{2}{*}{ Lake } & & \multicolumn{2}{|c|}{ Nanoflagellates } & \multicolumn{2}{|c|}{$\begin{array}{l}\text { Ophrydium } \\
\text { naumanni }\end{array}$} & \multicolumn{2}{|c|}{$\begin{array}{l}\text { Ceriodaphnia } \\
\text { dubia }\end{array}$} & \multicolumn{2}{|c|}{$\begin{array}{l}\text { Daphnia cf. } \\
\text { commutata }\end{array}$} \\
\hline & & $\begin{array}{c}\text { Ind CR } \\
\mu \mathrm{L} \mathrm{ind}^{-1} \mathrm{~h}^{-1}\end{array}$ & $\begin{array}{l}\text { Ass CR } \\
\mathrm{mL} \mathrm{L}^{1} \mathrm{~h}^{-1}\end{array}$ & $\begin{array}{c}\text { Ind CR } \\
\mu \mathrm{L} \text { ind }^{-1} \mathrm{~h}^{-1}\end{array}$ & $\begin{array}{c}\text { Pop CR } \\
\mathrm{mL} \mathrm{L}^{-1} \mathrm{~h}^{-1}\end{array}$ & $\begin{array}{c}\text { Ind CR } \\
\mathrm{mL} \text { ind }^{-1} \mathrm{~h}^{-1}\end{array}$ & $\begin{array}{c}\text { Pop CR } \\
\mathrm{mL} \mathrm{L}^{-1} \mathrm{~h}^{-1}\end{array}$ & $\begin{array}{c}\text { Ind CR } \\
\mathrm{mL} \mathrm{ind}^{-1} \mathrm{~h}^{-1}\end{array}$ & $\begin{array}{c}\text { Pop CR } \\
\mathrm{mL} \mathrm{L}^{-1} \mathrm{~h}^{-1}\end{array}$ \\
\hline \multirow[t]{2}{*}{ Moreno } & $10 \mathrm{~m}$ & 0.042 & 19.011 & 0.390 & 1.847 & 0.347 & 0.347 & - & - - \\
\hline & $30 \mathrm{~m}$ & 0.033 & 18.468 & 0.378 & 2.530 & 0.347 & 2.774 & - - & - - \\
\hline \multirow[t]{2}{*}{ Rivadavia } & $10 \mathrm{~m}$ & 0.018 & 5.169 & 0.240 & 1.247 & - - & - — & 1.766 & 0.000 \\
\hline & $30 \mathrm{~m}$ & 0.015 & 3.456 & 0.317 & 0.996 & - - & - — & 1.766 & 0.283 \\
\hline
\end{tabular}

et al. 2003). In addition, Villalobos (2002) indicated that D. commutata presented a fine filtration structure that may enhance filtering rates on bacteria.

Remarkably, the other components of the microbial food web of both lakes are nanoflagellates and ciliates, which are dominated largely by the same mixotrophic species, indicating that these species may be less constrained by the C:P ratio. Mixotrophy in algal flagellates has been considered to signal use of inorganic $\mathrm{N}$ and $\mathrm{P}$ when inorganic nutrients are in limited supply (Nygaard \& Tobiesen 1993). The difference observed in nanoflagellate assemblage clearance rates during the present study is likely to reflect an increase in the phagotrophy where luminous energy is high relative to phosphorus (Table 6). In lake Moreno Oeste, where light is not limiting, the observed increase of the phagotrophy may be due to a higher requirement of limiting elements. Studies on nutrient limitation have focused their attention on the fact that bacteria, like other members of the plankton, have specific requirements for mineral nutrients (Chrzanowski et al. 1996). However, bacteria may alter their cellular element composition as has been shown in an oligotrophic Canadian Shield lake (Chrzanowski et al. 1996). The quality of nutrient limiting resources is suboptimal for grazer production (Elser et al. 2001). Thus, herbivores may be confronted with nutritional constraints due to unfavourable supplies of energy relative to nutrient input for their food web (Urabe et al.
2002). In a high-light-nutrient-poor ecosystem like lake Moreno Oeste the quality of bacteria and APP is likely to be poor for bacterivorous nanoflagellates, driving them to increase their clearance rate (Table 6). In addition, the HNF were observed to be scarce in these two ultraoligotrophic Andean lakes, and therefore, differences cannot be attributed to these heterotrophic assemblages.

It has been suggested that the ciliate $O$. naumanni regulates light intensity for endosymbiotic photosynthesis by means of changing the availability of limiting elements obtained through phagotrophy (Modenutti \& Balseiro 2002). In an experimental study, particle ingestion by $O$. naumanni was observed to be light dependent as ingestion decreases under dark conditions (Modenutti \& Balseiro 2002). Therefore, an increase in light intensity would probably require more phagotrophy for the internal maintenance of the symbiotic consortium, i.e., as observed in lake Moreno Oeste (Fig. 4 and Table 6). At the same time, the deep distribution of $O$. naumanni in the water column would indicate that this ciliate adjusts its location to an optimal ratio between light intensity and availability of limiting elements obtained through phagotrophy. As a consequence of this deep distribution, $O$. naumanni reaches maximum population clearance rates in lake Moreno Oeste at the metalimnetic level $(30 \mathrm{~m})$. Remarkably, O. naumanni does not conform deep maxima in lake Rivadavia, and therefore population clearance rates do not differ substantially between 10 and $30 \mathrm{~m}$ depth. 
The different elemental ratios in the seston of lakes would determine, not only the potential presence of cladocerans like Daphnia, but also the grazing rates of mixotrophic protists in high-light:low-nutrient environments as Andean lakes.

\section{ACKNOWLEDGMENTS}

We are very grateful to Dr. Cristiana Callieri from the CNR-ISE Italy for providing us with the Synechococcus culture and for helpful discussion. To Lic. Gonzalo Pérez for his help in the field. To Dr. J.C.Paggi for his advice on the identity of Daphnia. Drs. E. Balseiro, C. Queimaliños and B. Modenutti are CONICET researchers. This research was supported by FONCYT PICT 01-06035, CONICET PIP 0739/98 and PIP 2175/01.

\section{LITERATURE CITED}

AMERICAN PUBLIC HEALTH ASSOCIATION (APHA) (1989) Standard methods for the examination of water, sewage, and wastewater. APHA, Washington, District of Columbia, USA. 715 pp.

ANDERSEN T \& DO HESSEN (1991) Carbon, nitrogen, and phosphorus content of freshwater zooplankton. Limnology and Oceanography 36: 807-814.

ARNDT H (1993) Rotifers as predators on components of the microbial web (bacteria, heterotrophic flagellates, ciliates) - a review. Hydrobiologia 255/ 256: 231-246.

BALSEIRO EG, BE MODENUTTI \& CP QUEIMALIÑOS (2001) Feeding of Boeckella gracilipes (Copepoda, Calanoida) on ciliates and phytoflagellates in an ultraoligotrophic Andean lake. Journal of Plankton Research 23: 849-857.

CALLIERI C \& JG STOCKNER (2002) Freshwater autotrophic picoplankton: a review. Journal of Limnology 61: 1-14.

CALLIERI C, SM KARJALAINEN \& S PASSONI (2002) Grazing by ciliates and heterotrophic nanoflagellates on picocyanobacteria in Lago Maggiore, Italy. Journal of Plankton Research 24: 785-796.

CHRZANOWSKI TH, M KYLE, JJ ELSER \& RW STERNER (1996) Element ratios and growth dynamics of bacteria in an oligotrophic Canadian shield lake. Aquatic Microbial Ecology 11: 119-125.

DEMOTT WR, RD GULATI \& K SIEWERTSEN (1998) Effects of phosphorus-deficient diets on the carbon and phosphorus balance of Daphnia magna. Limnology and Oceanography 43: 1147-1161.

ELSER JJ, WF FAGAN, RF DENNO, DR DOBBERFUHL, A FOLARIN, A HUBERTY, S INTERLANDI, SS KILHAM, E MCCAULEY, KL SCHULZ, EH SIEMANN \& RW STERNER (2000a) Nutritional constraints in terrestrial and freshwater food webs. Nature 408: 578-580.

ELSER JJ, RW STERNER, E GOROKHOVA, WF FAGAN, TA MARKOW, JB COTNER, JF
HARRISON, SE HOBBIE, GM ODELL \& LJ WEIDER (2000b) Biological stoichiometry from genes to ecosystems. Ecology Letters 3: 540-550.

ELSER JJ, K HAYAKAWA \& J URABE (2001) Nutrient limitation reduces food quality for zooplankton: Daphnia response to seston phosphorus enrichment. Ecology 82: 898-903.

GAULD DT (1951) The grazing rate of planktonic copepods. Journal of Marine Biological Association 29: 695-706.

GÜDE H (1989) The role of grazing on bacteria in plankton succession. In: Sommer U (ed) Plankton Ecology: 337-364. Springer-Verlag, New York, New York, USA.

HART R \& A JARVIS (1993) In situ determinations of bacterial selectivity and filtration rates by five cladoceran zooplankters in a hypereutrophic subtropical reservoir. Journal of Plankton Research 15: 295-315.

JONES RI (2000) Mixotrophy in planktonic protists: an overview. Freshwater Biology 45: 219-226.

JÜRGENS K (1994) Impact of Daphnia on planktonic microbial food webs- a review. Marine Microbial Food Webs 8: 295-324.

JÜRGENS K, H ARNDT \& KO ROTHHAUPT (1994) Zooplankton-mediated changes of bacterial community structure. Microbial Ecology 27: 27-42.

JÜRGENS K, H ARNDT \& H ZIMMERMANN (1997) Impact of metazoan and protozoan grazers on bacterial biomass distribution in microcosm experiments. Aquatic Microbial Ecology 12: 131-138.

KEMP PF, BF SHERR, EB SHERR \& JJ COLE (eds) (1993) Handbook of methods in aquatic microbial ecology. Lewis Publishers, Boca Ratón, Florida, USA. 777 pp.

MARTÍNEZ G (2000) Conducta alimentaria de Daphnia ambigua Scourfield 1947, Moina micrura Kurz 1874 y Ceriodaphnia dubia Richard 1895 (Cladocera) frente a un gradiente de concentración de alimento. Revista Chilena de Historia Natural 73: 47-54.

MATVEEV VF \& EG BALSEIRO (1990) Contrasting responses of two cladocerans to changes in the nutritional value of nannoplankton. Freshwater Biology 23: 197-204.

MODENUTTI BE \& EG BALSEIRO (2002) Mixotrophic ciliates in an Andean lake: dependence on light and prey of an Ophrydium naumanni population. Freshwater Biology 47: 121-128.

MODENUTTI BE, EG BALSEIRO, CP QUEIMALIÑOS, D AÑÓN SUÁREZ, MC DIÉGUEZ \& RJ ALBARIÑO (1998) Structure and dynamics of food web in Andean lakes. Lakes \& Reservoirs Research and Management 3: 179-186.

MODENUTTI BE, CP QUEIMALIÑOS, EG BALSEIRO \& M REISSIG (2003) Impact of different zooplankton structures on the microbial food web of an Andean oligotrophic lake. Acta Oecologica 24 S1:289-298.

NUSCH EA (1980) Comparison of different methods for chlorophyll and phaeopigment determination. Archiv für Hydrobiologie Beihtrage Ergebnisse der Limnologie 14: 14-36.

NYGAARD K \& A TOBIESEN (1993) Bacterivory in alga: A survival strategy during nutrient limitation. Limnology and Oceanography 38: 273-279.

PÉREZ GL, CP QUEIMALIÑOS \& BE MODENUTTI (2002) Light climate and plankton in the deep chlorophyll maxima in north Patagonian Andean lakes. Journal of Plankton Research 24: 591-599. 
PERNTHALER J, K SIMEK, B SATTLER, A SCHWARZENBACHER, J BOBKOVA \& R PSENNER (1996) Short-term changes of protozoan control on autotrophic picoplankton in an oligomesotrophic lake. Journal of Plankton Research 18: 443-462.

PETERSON BJ, JE HOBBIE \& JF HANEY (1978) Daphnia grazing on natural bacteria. Limnology and Oceanography 23: 1039-1044.

PORTER KG \& YS FEIG (1980) The use of DAPI for identifying and counting aquatic microflora. Limnology and Oceanography 25: 943-948.

QUEIMALIÑOS CP (2002) The role of phytoplanktonic size fractions in the microbial food webs in two north Patagonian lakes (Argentina). Verhandlungen Internationale Vereinigung Limnologie 28:1236-1240.

QUEIMALIÑOS CP, BE MODENUTTI \& EG BALSEIRO (1999) Symbiotic association of the ciliate Ophrydium naumanni with Chlorella causing a deep chlorophyll a maximum in an oligotrophic south Andes lake. Journal of Plankton Research 21: 167-178.

SANDERS RW, KG PORTER, SJ BENNETT \& AE DEBIASE (1989) Seasonal patterns of bacterivory by flagellates, ciliates, rotifers, and cladocerans in a freshwater planktonic community. Limnology and Oceanography 34: 673-687.

SHERR EB \& BF SHERR (1993) Protistan grazing rates via uptake of fluorescently labelled prey. In: Kemp PF, BF Sherr, EB Sherr \& JJ Cole (eds) Handbook of methods in aquatic microbial ecology: 695-701. Lewis Publisher, Boca Ratón, Florida, USA.

SHERR FB, EB SHERR \& RD FALON (1987) Use of monodispersed fluorescently labelled bacteria to estimate in situ protozoan bacterivory. Applied and Environmental Microbiology 53: 958-965.

SIMEK K, J ARMENGOL, M COMERMA, JC GARCÍA, TH CHRZANOWSKI, M MACEK, J NEDOMA \& V STRASKRABOVA (1998) Characteristics of protistan control of bacterial production in three reservoirs of different trophy. International Review of Hydrobiology 83: 485-494.
STERNER RW (1993) Daphnia growth on varying quality of Scenedesmus - mineral limitation of zooplankton. Ecology 74: 2351-2360.

STERNER RW \& DO HESSEN (1994) Algal nutrient limitation and the nutrition of aquatic herbivores. Annual Review Ecology Systematics 25: 1-29.

STERNER RW, TH CHRZANOWSKI, JJ ELSER \& NB GEORGE (1995) Sources of nitrogen and phosphorus supporting the growth of bacterio- and phytoplankton in an oligotrophic Canadian shield lake. Limnology and Oceanography 40: 242-249.

STERNER RW, JJ ELSER, EJ FEE, SJ GUILDFORD \& TH CHRZANOWSKI (1997) The light:nutrient ratio in lakes: the balance of energy and materials affects ecosystem structure and process. American Naturalist 150: 663-684.

STERNER RW, JH SCHAMPEL, KL SCHULZ, AE GALFORD \& JJ ELSER (2000) Joint variation of zooplankton and seston stoichiometry in lakes and reservoirs. Verhandlungen Internationale Vereinigung Limnologie 27: 3009-3014.

URABE J, M KYLE, W MAKINO, T YOSHIDA, T ANDERSEN \& JJ ELSER (2002) Reduced light increases herbivore production due to stoichiometric effects of light/nutrient balance. Ecology 83: 619-627.

UTERMÖHL H (1958) Zur Vervollkommnung der quantitativen Phytoplankton-Methodik. Internationalen Vereinigung für Theoretische und Angewandte Limnologie 9: 1-38.

VAQUÉ D \& M PACE (1992) Grazing on bacteria by flagellates and cladocerans in lakes of contrasting food-web structure. Journal of Plankton Research 14: 307-321.

VILLALOBOS L (2002) Comparison of the filtration structure in South American Daphnia. Archiv für Hydrobiology 154: 647-663.

WOELFL \& GELLER (2002) Chlorella-bearing ciliates dominate in an oligotrophic North Patagonian lake (Lake Pirehueico, Chile): abundance, biomass and symbiotic photosynthesis. Freshwater Biology 47: 231-242. 